\title{
Xerodrymionorientale mediterraneum gorges of the Karatag river
}

\author{
Sayfiddin Khairiddin Davlatov ${ }^{{ }^{*}}$, Rakhmatullo Boboevich Sattorov ${ }^{2}$, Jamoliddin \\ Murotalievich Bobokalonov ${ }^{2}$ \\ ${ }^{1}$ Bokhtar State University named after Nosir Khusrav, 735240, Bokhtar, Tajikistan \\ ${ }^{2}$ Tajik National University, 734025 Dushanbe, Republic of Tajikistan
}

\begin{abstract}
The Karatag gorge is one of the natural areas where valuable genetic resources (wild, fruit and many valuable species) are preserved. A characteristic feature of the region is the richness of the diversity of flora and vegetation, where the main formations of Tajik vegetation are noted (maple, hazel, almond, frame, juniper). The article summarizes the results of the authors' field research on the study of the state of xerophilic forests in the Karatag gorge. For the first time, the authors cite original materials on the phytocenology of all formations of this type of composition. According to the results of our research, the Shibleak communities in the study area are distributed in high-altitude belts from low-hilly $600-800 \mathrm{~m}$ to middle mountains $800-1800,2000 \mathrm{~m}$. The main formations of this type in the study area are: Acer regelii, Crataegus pontica, Celtis caucasic, Pistacia vera, Amygdalis bucharica, Ampelopsis vitifolia, Atraphaxis pyrifolia. As a result of the study, 340 plant species, 6 formations and more than 25 vegetation associations were identified in the composition of the flora of this type of the study area.
\end{abstract}

\begin{abstract}
Within Tajikistan, the study area plays a role in creating ecological corridors and ecological network of the region, without which it is impossible to preserve populations of valuable plant and animal species. With the increasing demand of the population for products and goods of plant origin, as well as for eco-system services, the anthropogenic influence on the flora and vegetation of Tajikistan, including mountainous areas, is increasing [1]. In this regard, it became relevant to study the composition and structure of vegetation and predict the direction of their development in the long term, which is especially important for mountainous areas, where local, to a certain extent isolated, phytocenotic and floristic complexes are formed on small areas. These studies make it possible to trace the genesis and dynamics of the development of flora and vegetation, help to obtain information for the development of design and program documents on rational environmental management, facilitate the adaptation of economic activities to complex physical, geographical and environmental factors, and determine the criteria and conditions for limiting the impact on ecosystems.

The main goal of the study is to analyze the aspects of adaptation of arboreal and shrub vegetation belts in the Karatog gorge of the southern slope of the Gissar ridge.
\end{abstract}

\footnotetext{
*Corresponding author: s.davlatov@mail.ru
} 
Methodology. When performing, the methods of the Soviet (Russian) geobotanical school were used $[2,3,4]$. More than 100 geobotanical descriptions are given to reveal the composition of vegetation communities and to establish typical phytocenoses.

In parallel with the geobotanical descriptions, samples of vascular plants were collected at the sites. Typological classification of vegetation and identification of florocoenotypes, formations, groups of associations and associations was carried out on the basis of the principles [5]. The main period of the formation and formation of the "shiblyak", as a part of the ancient Mediterranean florocoenotype, formed in the Neogene from the complex "proshiblyak", R.V. Kamelin [5, 6] for mountainous Central Asia dates from the postPleistocene xerothermal period [7]. Thus, many formations of the Shiblyak type that are now preserved in different areas of the studied province are of autochthonous origin and are the result of natural successional processes in the South Pamir-Alai [1]. The morphoecological type "shiblyak" is here in a full-fledged natural state, not counting some anthropogenic negative manifestations.

Shiblyak communities are widespread in high-altitude belts from low-hilly (600-800 m) to middle mountains $(800-1800,2000 \mathrm{~m})$. The main formations of this type are: maple (Acer regelii), hawthorn (Crataegus pontica), scarlet (Cercis griffithii), carcass (Celtis caucasica), chylon (Zizyphus jujuba), pistachios (Pistacia vera), green leaves (Zigrovophyllum gontschallum gonts bucharica), bodomchi (Amygdalis spinosissima), vine (Ampelopsis vitifolia), curl (Atraphaxis pyrifolia) and pomegranate (Punica granatum) [1, $2,5,8,9,7]$. We would like to note that the materials on the xerophilic forests of the Karatag gorge have not yet been presented and $[1,5,11,12,13,14,15,16,17,18]$ are of a general nature.

As a result of the study, 340 plant species, 6 formations and more than 25 vegetation associations were found in the composition of this type of flora in the Karatag gorge. Below is a brief description of the formations of this type of vegetation.

Regel Maple Formation (Acer regelii). This formation is a typical representative of deciduous xerophytic sparse forests, but often mesophilic species penetrate into maple forests even at altitudes from 800 to $2000 \mathrm{~m}$ above sea level. rather stable two-dominant communities are formed in the sea. The communities of Acer regelii within the study area grow on gray soils and partially on brown soils. They are common in the Shiblyak belt at altitudes of 1000-2000 m. [1]. In the composition of the formations, 74 species of vascular plants have been described 2 groups of associations: forbs, yugan-ferul-barley and 4 associations with predominance in the herbage: Prangos pabularia, Ferula kuhistanica, Hordeum bulbosum, Bothriochloa ischaemum, Dactylis glomerata, Aegcialis and many others. Ornamental plant.

Hawthorn formation (Crataegus pontica). Phytocenoses of Pontic hawthorn have been recorded in the study area within heights from 800 to $1800 \mathrm{~m}$. Almost everywhere they have a secondary origin, especially on the plains, since the areas of the latter were used for crops for a long time, and later and up to the present time - as fallow pastures and hayfields, which contributed to the secondary development of these species [1]. This community contains 135 species of vascular plants, and among the herbaceous species dominate abundantly: Hordeum bulbosum, Prangos pabularia, Hyepericum perforatum, Origanum tyttanthum, etc. There are few shrubs in the formation: Kokand rose hips, Irgai Hissar. The formation includes cornflower - barley - hedgehog hawthorns, herb adzhirekovo - bearded hawthorns, ephemeroid - licorice hawthorns and ephemeroid hawthorns. In some areas, it occurs as an admixture in broadleaf forests. Wild, fruit and food plant $[18,20]$.

Frame formation (Celtis caucasica). Communities of this formation are widespread in the belt of xerophytic light forests (shiblyak) throughout the southern Pamir-Alai [1]; sometimes the framework is found in mesophytic forests (black forest). It should be noted 
that in rocky areas, the framework is also actively introduced into hazel and maple forests [1]. In the study area, skeletons are found in the range of heights from 1000 to 1800 (2000 $\mathrm{m})$. They are mixed in the composition of almonds, regellocens, turkestanoklens and hazels. Sometimes, together with walnut and oriental sycamore, it forms rather high-density nemoral communities with a multi-tiered structure.

As a result of the study, 85 species of plants were noted in the composition of the frame. In the composition of the formation of shrubs, (Caragana turkestanicus, Rosa divina) are noted, often nemoral herbaceous plants penetrate into their composition, such as: (Poa nemoralis, Impatiens parviflora, Aegopodium tadshikorum). Carcasses in the gorge are represented by one group of associations: semi-savannah carcasses (Celtis caucasica, Hordeum bulbosum, Inula grandis, Elytrigia trichophora, Hypericum perforatum). Savannah herbaceous plants (Prangos pabularia, Hordeum bulbosum, Inula grandis, Elytrigia trichophora, Hypericum perforatum) are codominants in the frame communities. Wild, fruit and food plant $[18,20]$.

Pistachio formation (Pistacia vera). Pistachio trees, in comparison with maple trees, calofashniks and almonds, occupy low gypsomfetric levels $(800-1800 \mathrm{~m})$ and are much less widespread. Large areas of pistachio woodlands are found in the lower part of the Karatag gorge. In some places, the pistachio community includes maple, almond, honeysuckle, and small xerophytic shrubs [1]. The formation includes 65 species of vascular plants. Among the herbaceous species, it was noted (Elytrigia trichophora, Hypericum perforatum) and ephemeris. As a result of monitoring, the following group of associations was revealed in the community: bluegrass-sedge, bluegrass-sedge-wormwood, ephemeral-ephemeroid, barley, elecampane, yugan, camola pistachios. Flomis Bukhara and Kachim (Crambe cochianum, Phlomis bucharica), with the participation of almonds and maple (Amygdalus bucharica, Acer regelii), sometimes pear, juniper, kalofaka, pyrus and hawthorn, (Acer, Crataegus pontica, Juniperus seravschanica), rose (Rosa ecae). Wild, fruit and food plant [21].

Almond Formation (Amygdalus bucharica). Edificator is a tree from the Rosaceae family. Almond trees in the composition of xerophilic light forests, sometimes mesophytic forests, spread to the northern part of the region and spread at altitudes from 700-800 to $2000 \mathrm{~m}$ above sea level. Seas As a part of almonds, 118 species of flowering plants are noted and forms 4 associations: forbs yugan, ferul, bluegrass sedge and others. Almonds, like purple plants, usually form pioneer communities on steep slopes of various exposures in place of pistachios, carcasses and regelens. Under natural conditions they reproduce well by seeds. Wild, fruiting species [20].

Sumach Formation (Rhus coriaria L.). Edificator is a tree from the sumach family. Sumakh forms a formation as part of a xerophilic light forest. In the Karatag gorge, Sumakh communities are noted at altitudes from 800 to $1800 \mathrm{~m}$ above sea level. More than 124 species have been recorded in the composition of madmen and the following three groups of associations have been identified: ephemeral, ephemeral-Yugan, and large-grasssavanna. These communities are dominated by (Inula macrophylla, Prangos pabularia, Bromus oxyodon, Botriochloa iscaemum, Aegilops triunsialis, etc.). Wild fruit and medicinal plant [22]. Our studies have shown that $25 \%$ of the state of the coenoses of the madmen in the gorge is disturbed by intense anthropogenic influences from the population as a source of food and medicine. Wild, fruit and food plant. In conclusion, we would like to note that communities of xerophilous forests in the study area are widespread in highaltitude belts from low-hilly $(600-800 \mathrm{~m})$ to middle mountains $800-1800 \mathrm{~m}$. Caucasian. According to our research, over the past 20 years, $30-35 \%$ of the composition of madmen has been disrupted as a result of anthropogenic impact (land development, collection of useful plants, overgrazing, construction of houses and summer cottages, deforestation).

Based on this, we propose the following activities: 
- to carry out work on the restoration of plant communities;

- to regulate the grazing of small and large horned livestock, to carry out pasture rotation;

-prohibit the collection of those plant species that are listed in the Red Book of Tajikistan, related to rare or endangered species.

\section{References}

1. N. M. Safarov, Flora and vegetation of the southern Pamir-Allai (Dushanbe, 2015)

2. E. M. Lavrenko, V. M. Sveshnikova, Botanical geography and phytocenology (geobotany) (Moscow, Nauka, 1967)

3. L. G. Ramenskiy, Problems and methods of studying the vegetation cover (L., Nauka, 1971)

4. R. B. Sattorov, Vegetation of the Karateginsky ridge and questions of its mapping based on space survey materials (Dushanbe, 1995)

5. G. T. Sidorenko, Vegetation cover of South-West Tajikistan (Dushanbe, 1993)

6. R. V. Kamelin, Kuhistan district of mountainous Central Asia (botanical and geographical analysis) (L., Nauka, 1979)

7. R. V. Kamelin, Florogenetic analysis of the natural flora of Mountainous Central Asia (L., Nauka, 1973)

8. Yu. S. Grigoriev, A. S. Koroleva, V. A. Nikitin, Proceedings of the Tajik Academy of Sciences of the USSR 2 (1936)

9. N. G. Kaletkina, Reports of the Academy of Sciences of the Tajik SSR 9(4) (1966)

10. A. Kh. Khalimov, Vegetation cover of the key area of the central part of the Khazrati Shokh ridge (Tajikistan) (L., 1988)

11. NP Akulshina, Scientific notes of the Tajik University. in I. Lenin. 1 (1970)

12. Kh. R. Atakhanov, Bagryanniki of Tajikistan (Dushanbe, 1992)

13. K. S. Afanasyev, Reports of the Academy of Sciences of the Tajik SSR 8 (1940)

14. L. N. Babushkin, N. A. Kogai, Questions of geographic zoning of Central Asia and Uzbekistan, 307 (1967)

15. V. N. Vladimirova, Tajikistan (Nature and natural resources) (Dushanbe, Donish, 1968)

16. N. F. Goncharov, Flora of Tajikistan (M.-L., Publishing house of the Academy of Sciences of the USSR, 1937)

17. S. Kh. Davlatov, Wild species of the genus Berberis L. in Tajikistan (Dushanbe, Donish, 2019)

18. N. K. Eremina, The main wild-growing useful plants of Tajikistan (Dushanbe, Donish, 1983)

19. V. I. Zapryagaeva, Wild-growing fruits of Tajikistan (M.-L., Nauka, 1964)

20. V. I. Zapryagaeva, Forest resources of the Pamir-Alai (L., Nauka, 1976)

21. M. I. Ismailov, A. Halimov, R. B. Sattorov, Flora of vascular plants of the reserve "Dashti jum" (Dushanbe, 1998)

22. N. F. Goncharov, Reports of the Academy of Sciences of the Tajik SSR 8 (1940) 